\title{
IDENTIFIKASI KUALITAS MATA AIR SEBAGAI SUMBER AIR MINUM TANPA PENGOLAHAN DI DESA KUKUH, KECAMATAN MARGA, KABUPATEN TABANAN, BALI, TAHUN 2018
}

\section{IDENTIFICATION THE QUALITY OF SPRINGS AS A SOURCE OF DRINKING WATER WITHOUT PROCESSING IN KUKUH VILLAGE, MARGA DISTRICT, TABANAN REGENCY, BALI, IN 2018}

\author{
Ni Luh Nova Dilisca Dwi Putri ${ }^{1)}$, Nyoman Sudarma ${ }^{2}$, Diah Prihatiningsih ${ }^{3)}$ \\ 1) STIKes Wira Medika Bali
}

\begin{abstract}
ABSTRAK
Pendahuluan : Air merupakan sumber daya alam yang dilukan untuk hajat hidup orang banyak (Efendi, 2003). Berdasarkan . Men. Kes. No. 492/MENKES//IV/2010, bahwa air minum adalah air yang melalui proses pengolahan atau tanpa pengolahan memenuhi syarat kesehatan dapat langsung diminum. Desa Kukuh, Kecamatan Marga, Kabupaten Tabanan terbagi menjadi 8 banjar dinas, salah satunya adalah banjar dinas Tatag yang menjadi pusat dalam pemanfaatan sumber mata air minum pada wilayah desa tersebut. Metode: Jenis penelitian yang digunakan adalah penelitian deskriptif tentang uji kelayakan kualitas air berdasarkan parameter kimia dan mikrobiologi dari sumber mata air di Desa Kukuh, Kecamatan Marga, Kabupaten Tabanan. Hasil: Hasil identifikasi kelayakan kualitas air minum yang telah dilakukan sebanyak tiga kali pengujian, yaitu pada bulan (Mei, Juli, September) pada tahun 2018 memberikan hasil: a). Pemeriksaan parameter kimia menunjukkan bahwa seluruh parameter yang diujikan berada pada standar yang dibolehkan, sedangkan b). Pemeriksaan parameter mikrobiologi menunjukkan hasil adanya kandungan bakteri Fecal coli pada sampel mata air dengan jumlah rata-rata $100 \mathrm{Fecal}$ coli/100 mL. Diskusi : Berdasarkan hasil identifikasi pada parameter kimia menunjukkan bahwa hasil identifikasi parameter kimia telah sesuai dengan standar kualitas air minum, sedangkan parameter mikrobiologi belum memenuhi standar kualitas air minum disebabkan adanya kandungan bakteri Fecal coli pada sampel mata air dengan jumlah rata-rata $100 \mathrm{Fecal} \mathrm{coli} / 100 \mathrm{~mL}$.
\end{abstract}

Kata Kunci : Kualitas mata air, Parameter Kimia, Parameter Mikrobiologi.

\begin{abstract}
Introduction: Water is a natural resource needed for the livelihood of many people. Drinking water is water with or without processing that meet health requirements and can be drunk directly, this is based on. Men Kes No. 492/MENKES//IV/2010. Kukuh Village, Marga District, Tabanan Regency is divided into 8 banjar dinas, one of which is the Banjar Tagtag, which is the center of the utilization of drinking water sources in the village area. Method: The type of research used is a descriptive study of the feasibility of water quality based on chemical and microbiological parameters on water from a spring source in Kukuh Village, Marga District, Tabanan Regency. Results: The results of the identification of the feasibility of drinking water quality that has been carried out three times th the
\end{abstract}


month of May, July, and September. The results of the identification of chemical and microbiological parameters were : a). Chemical parameters, showed that all identified parameters are at the missible level. c). Microbiological parameters showed the results of Fecal coli contents in spring samples with and an average number of $100 \mathrm{Fecal}$ coli/100 mL. Discussion: The results of the identification of chemical and microbiological parameters indicated that the identification of chemical parameters were in accordance with drinking water quality standards, while the microbiological parameters did not meet drinking water quality standards, because in the water sample there was the content of Fecal coli bacteria in the spring samples with and average number of $100 \mathrm{Fecal}$ coli/100 mL.

Keywords : Quality of Springs, Chemical Parameters, Bacteriological Parameters.

\section{PENDAHULUAN}

Air merupakan sumber daya alam yang dilukan untuk hajat hidup orang banyak. Aspek penghematan dan pelestarian sumber daya air harus ditanamkan pada segenap pengguna air (Efendi, 2003). Berdasarkan aturan Mentri Kesehatan Nomor 492/MENKES//IV/2010 tentang syaratan kualitas kualitas air minum, bahwa air minum adalah air yang melalui proses pengolahan atau tanpa pengolahan yang memenuhi syarat kesehatan dan dapat langsung diminum.

Desa Kukuh terbagi menjadi 8 banjar dinas, salah satunya adalah banjar dinas Tatag. Banjar dinas Tatag menjadi pusat dalam pemanfaatan sumber mata air minum pada wilayah Desa tersebut, wilayah banjar tersebut memiliki lokasi sumber mata air. Masyarakat pada umumnya langsung menampung air dari sumber mata air tersebut ke dalam wadah dan dikonsumsi tanpa dimasak terlebih dahulu karena menurut masyarakat air dari sumber mata air terhindar dari pencemaran.

Tingginya aktifitas tanian pada daerah sumber mata air di wilayah banjar dinas Tagtag berpotensial menyebabkan berbagai cemaran pada mata air, dimana syarat sumber mata air yang dapat digunakan menjadi air minum yaitu air harus memenuhi baku mutu kualitas air minum baik itu dari sisi fisika, kimia, maupun mikrobiologis. Salah satu bahan pencemar air di daerah tanian berasal dari pupuk kimia yang mengandung unsur nitrogen (Ompusunggu, 2009). Rata-rata setiap pemukiman penduduk di banjar dinas Tagtag memiliki minimal satu kandang hewan ternak seti babi, ayam, ataupun bebek, dimana jarak antara kandang ternak dengan sumber mata air sangat berdekatan. Hal tersebut dapat menyebabkan kontaminasi bakteri Escherichia colli terhadap sumber mata air yang berasal dari kotoran hewan ternak tersebut. Penggunaan sumber mata air sebagai tempat mandian dan mencuci pakaian juga tentunya berpotesi menyebabkan terjadinya pencemaran kimia dari sisa hasil buangan limbah pencucian.

Penelitian yang dilakukan oleh Rahmawati (2015) di Kecamatan Karangploso Kabupaten Malang mengenai "Studi Kelayakan Kualitas Air Minum Delapan Mata Air Di Kecamatan Karang ploso Kabupaten Malang" meyatakan bahwa dari hasil penelitian menunjukkan bahwa delapan mata air yang dipantau sudah tidak layak digunakan sebagai bahan baku air minum dari segi kimiawi, parameter yang tidak memenuhi baku mutu yang ditetapkan yaitu nilai DO, BOD, dan nitrat. Khatun (2016) melakukan pengujian terhadap "Kualitas Air Dari Mata Air Dampit dan Petung Kecamatan Windusari Kabupaten Magelang Jawa Tengah" 
menyatakan bahwa air dari mata air Petung dan Dampit tidak memenuhi stadar baku mutu air minum dari segi mikrobiologis dengan adanya kandungan bakteri E.colli. Putri, dkk (2018) telah melakukan penelitian terhadap sumber air minum di Banjar Tatag, Desa Kukuh, Kecamatan Marga, Kabupaten Tabanan dengan parameter fisika dan mikrobiologi dan teridentifikasi air dari mata air tersebut dilihat dari parameter fisika terdapat peningkatan suhu yaitu rata-rata sebesar $24,43^{\circ} \mathrm{C}$ dan teridentifkasi adanya kandungan bakteri Coliform dengan jumlah ratarata 124 Coliform $/ 100 \mathrm{~mL}$.

Ahli hidrogeologis dari Universitas Pembangunan Nasional, dalam berita harian Pos Kupang, Bahagiarti (2010) menyebutkan sumber air minum terbaik berasal dari mata air pegunungan vulkanik yang berasal dari air tanah dalam. Hal tersebut didasari oleh penjelasan ilmiah yaitu air pegunungan vulkanik relatif bebas pencemaran, mengandung mineral alami yang seimbang, dan memenuhi syarat kualitas air. Pada berita tersebut Oetoro (2010) seorang ahli nutrisionis juga menambahkan bahwa kualitas air yang diminum lu memiliki karakteristik yang sesuai dengan standar kesehatan seti tidak berwarna, tidak berbau, tidak berasa, bebas dari bahan kimia berbahaya maupun bakteri. Sementara, daerah banjar Tatag, Desa Kukuh merupakan wilayah dataran rendah dan lokasinya cukup jauh dari wilayah pegunungan, namun menjadi pusat sumber mata air langsung minum di wilayah Desa Kukuh, Kecamatan Marga, Kabupaten Tabanan.

Berdasarkan latar belakang diatas, maka penulis berkeinginan untuk melakukan identifikasi kualitas air berdasarkan parameter kimia dan mikrobiologi di Desa Kukuh, Kecamatan Marga, Kabupaten Tabanan. Mengingat warga wilayah desa tersebut mengkonsumsi air dari sumber mata air diwilayah tersebut tanpa pengolahan terlebih dahulu. Hal ini tentunya sangat penting untuk dilakukan karena air adalah sumber kehidupan, sehingga apabila kualitas air tetap terjaga baik tentunya akan berdampak baik bagi kehidupan serta kualitas kesehatan masyarakat.

\section{Jenis Penelitian}

\section{BAHAN DAN METODE}

Jenis penelitian yang digunakan adalah penelitian deskriptif tentang uji kelayakan kualitas air berdasarkan parameter kimia dan mikrobiologi pada air dari sumber mata air di Desa Kukuh, Kecamatan Marga, Kabupaten Tabanan, Bali. Jenis penelitian deskriptif adalah penelitian yang mendeskripsikan suatu gejala, istiwa, kejadian yang terjadi pada saat sekarang (Sudjana dan Ibrahim, 2004).

\section{Waktu dan Tempat Penelitian Waktu Penelitian}

Waktu pemeriksaan sampel dilakukan pada bulan Mei 2018 sampai dengan bulan September 2018.

\section{Tempat Penelitian}

Pengambilan sampel dilaksanakan di Banjar Tatag, Desa Kukuh, Kecamatan Marga, Kabupaten Tabanan, Bali. Pemeriksaan sampel dilakukan berdasarkan parameter (kimia dan mikrobiologi) dilaksanakan di UPT Balai Laboratorium Kesehatan Provinsi Bali. 


\section{Populasi dan Sampel \\ Populasi}

Populasi dalam penelitian ini yaitu air dari sumber mata air di Banjar Tatag, Desa Kukuh, Kecamatan Marga, Kabupaten Tabanan.

\section{Sampel}

Sampel dalam penelitian ini yaitu sumber mata air di Desa Kukuh, Kecamatan Marga, Kabupaten Tabanan.

\section{Prosedur Penelitian Metode}

Metode penelitian yang digunakan dalam identifikasi pada parameter kimia adalah sebagai berikut: Fluorida dengan metode SPAND; Nitrit, Sianida dan Mangan dengan menggunakan metode Kolorimetri; Nitrat menggunakan metode Brucine; Besi dengan metode phenantrolin; kesadahan dan khlorida menggunakan metode titrasi; $\mathrm{pH}$ dengan metode elektrometri; Sulfat dengan metode turbidymetri; Ammonia metode Nessler; dan untuk Seng, Tembaga, Chrom, Kadmium, Selenium, Aluminium, Nikel, dan Arsen dengan menggunakan metode AAS. Metode penelitian yang digunakan dalam identifikasi mikrobiologi adalah metode MPN.

Metode pengambilan sampel adalah dengan botol kaca yang telah disterilkan dan berwarna gelap digunakan sebagai wadah sampel air untuk pemeriksaan parameter bakteri. Botol dibilas dengan air sampel sebanyak 3 kali. Sampel kemudian ditampung pada botol kemudian ditutup rapat. Botol kemudian diberi label dan dibawa ke laboratorium. Jerigen digunakan sebagai wadah sampel air untuk pemeriksaan parameter fisika dan kimia. Botol dibilas dengan air sampel sebanyak 3 kali. Sampel kemudian ditampung pada botol kemudian ditutup rapat. Botol kemudian diberi label dan dibawa ke laboratorium.

\section{HASIL}

Hasil penelitian tentang "Identifikasi Kualitas Air Pada Sumber Mata Air Minum Tanpa Pengolahan Di Desa Kukuh, Kecamatan Marga, Kabupaten Tabanan, Bali Tahun 2018" berdasarkan parameter kimia dan mikrobiologi menunjukkan bahwa dari hasil pengujian kelayakan kualitas air minum yang telah dilakukan sebanyak 3 kali pemeriksaan pada bulan (Mei, Juli, September) menunjukkan hasil: a). Parameter kimia menunjukkan bahwa seluruh parameter yang diujikan berada pada standar yang dibolehkan. b). Parameter mikrobiologi menunjukkan hasil adanya kandungan bakteri Fecal coli pada sampel mata air dengan jumlah rata-rata $100 \mathrm{Fecal}$ coli/100 mL. 
Tabel 1. Hasil Pemeriksaan Parameter Kimia, dan Mikrobiologi Pada Sampel Air Sumber Mata Air di Desa Kukuh, Kecamatan Marga, Kabupaten Tabanan.

$\begin{array}{ccc}\text { Para } & \text { Hasil Rata-rata } & \text { Kadar } \\ \text { meter } & \text { Selama } 3 \text { kali identifikasi } & \text { Maksimum } \\ & \text { menkes No: } \\ & 492 / \text { MENKES// } \\ & \text { IV/2010 }\end{array}$

\begin{tabular}{|c|c|c|c|}
\hline \multirow[t]{20}{*}{ Kimia } & Fluorida & 0,337 & $1,5 \mathrm{mg} / \mathrm{L}$ \\
\hline & Nitrit & $<0,001$ & $3 \mathrm{mg} / \mathrm{L}$ \\
\hline & Nitrat & 7,441 & $50 \mathrm{mg} / \mathrm{L}$ \\
\hline & Sianida & $<0,002$ & $0,07 \mathrm{mg} / \mathrm{L}$ \\
\hline & Besi & 0,018 & $0,3 \mathrm{mg} / \mathrm{L}$ \\
\hline & Kesadahan & 177,23 & $500 \mathrm{mg} / \mathrm{L}$ \\
\hline & Khlorida & 15,45 & $250 \mathrm{mg} / \mathrm{L}$ \\
\hline & Mangan & $<0,01$ & $0,4 \mathrm{mg} / \mathrm{L}$ \\
\hline & $\mathrm{Ph}$ & 6,55 & $6,5-8,5 \mathrm{mg} / \mathrm{L}$ \\
\hline & Sulfat & 22,322 & $250 \mathrm{mg} / \mathrm{L}$ \\
\hline & Ammonia & 0,017 & $1,5 \mathrm{mg} / \mathrm{L}$ \\
\hline & Seng & 0,1256 & $3 \mathrm{mg} / \mathrm{L}$ \\
\hline & Tembaga & $\operatorname{Ttd}(<0,0153)$ & $2 \mathrm{mg} / \mathrm{L}$ \\
\hline & Timbal & $\operatorname{Ttd}(<0,0036)$ & $0,01 \mathrm{mg} / \mathrm{L}$ \\
\hline & Chrom & $\operatorname{Ttd}(<0,001)$ & $0,05 \mathrm{mg} / \mathrm{L}$ \\
\hline & Kadminium & $\operatorname{Ttd}(<0,001)$ & $0,003 \mathrm{mg} / \mathrm{L}$ \\
\hline & Selenium & $\operatorname{Ttd}(<0,0006)$ & $0,01 \mathrm{mg} / \mathrm{L}$ \\
\hline & Aluminium & $\operatorname{Ttd}(<0,01)$ & $0,2 \mathrm{mg} / \mathrm{L}$ \\
\hline & Nikel & $\operatorname{Ttd}(<0,0003)$ & $0,07 \mathrm{mg} / \mathrm{L}$ \\
\hline & Arsen & $\operatorname{Ttd}(0,0003)$ & $0,01 \mathrm{mg} / \mathrm{L}$ \\
\hline $\begin{array}{l}\text { Mikrobiol } \\
\text { ogi }\end{array}$ & Fecal colli & $\begin{array}{l}100 \text { Fecal colli/ } \\
100 \mathrm{~mL}\end{array}$ & $\begin{array}{l}0 \text { Fecal colli/ } 100 \\
\mathrm{~mL}\end{array}$ \\
\hline
\end{tabular}




\section{PEMBAHASAN}

Penelitian tentang "Identifikasi Kualitas Air Pada Sumber Mata Air Minum Tanpa Pengolahan Di Desa Kukuh, Kecamatan Marga, Kabupaten Tabanan, Bali Tahun 2018. Penelitian ini bertujuan untuk untuk mengetahui kelayakan kualitas air pada sumber mata air minum tanpa pengolahan di Desa Kukuh, Kecamatan Marga, Kabupaten Tabanan berdasarkan parameter kimia dan mikrobiologi. Selain itu, bertujuan untuk mengetahui apakah hasil yang dioleh telah sesuai dengan standar kualitas air minum yang ditetapkan pada aturan Menteri Kesehatan Nomor 492/MENKES//IV/2010 tentang syaratan kualitas kualitas air minum.

Pemilihan lokasi penelitian sumber mata air minum di Desa Kukuh, Kecamatan Marga, Kabupaten Tabanan dikarenakan di Desa Kukuh, Banjar dinas Tagtag menjadi pusat dalam pemanfaatan sumber mata air minum pada wilayah Desa tersebut, wilayah banjar tersebut memiliki lokasi sumber mata air. Masyarakat pada umumnya langsung menampung air dari sumber mata air tersebut ke dalam wadah dan dikonsumsi tanpa dimasak terlebih dahulu karena menurut masyarakat air dari sumber mata air terhindar dari pencemaran. Air dari sumber mata air yang langsung dikonsumsi dan tanpa melalui pengolahan, tentu memungkinkan mengakibatkan masalah pada kesehatan masyarakat yang mengkonsumsi air secara langsung (Omposunggu, 2009).

Sehingga, dilakukanlah identifikasi terhadap sumber mata air minum tanpa pengolahan di Desa Kukuh, Kecamatan Marga, Kabupaten Tabanan untuk mengetahui kelayakan sebagai air minum langsung tanpa pengolahan, dan hasil identifikasi tersebut dibahas dengan ketentuan baku mutu air minum yang tercantum dalam aturan Mentri Kesehatan Nomor 492/MENKES/PER/IV/2010 tentang syaratan kualitas kualitas air minum.

Pada penelitian ini dilakukan pengambilan sampel sebanyak tiga kali pada sumber mata air, yaitu pada bulan Mei, Juli, dan September. Tujuan dilakukannya tiga kali pemeriksaan pada parameter (kimia dan mikrobiologi) adalah untuk mengetahui sejauh mana tingkat kestabilan dari hasil yang dioleh terhadap sampel tersebut.

a). Parameter Kimia

Pemeriksaan parameter kimia yang dilakukan meliputi: fluorida, nitrit, nitrat, sianida, besi, kesadahan, khlorida, mangan, $\mathrm{pH}$, sulfat, ammonia, seng, tembaga, timbal, chrom, cadmium, selenium, aluminium, nikel, dan arsen. Berdasarkan hasil pemeriksaan pada parameter kimia yang dilakukan sebanyak tiga kali berturut - turut pada bulan Mei, Juli, dan September memberikan hasil sebagai berikut:

Rata-rata hasil pengujian $\mathrm{pH}$ pada sampel air menunjukkan nilai $\mathrm{pH}$ air 6,55, menunjukkan hasil yang sesuai dengan standar yang disyaratkan pada . Men. Kes. No. 492/MENKES/PER/IV/2010, dimana $\mathrm{pH}$ sangat penting sebagai parameter kualitas air karena mengontrol tipe dan laju kecepatan reaksi beberapa bahan di dalam air. Selain itu mahluk-mahluk akuatik lainnya hidup pada selang $\mathrm{pH}$ tertentu, sehingga dengan diketahuinya nilai $\mathrm{pH}$ maka akan diketahui apakah air tersebut sesuai atau tidak untuk menunjang kehidupan. Kesadahan $\left(\mathrm{CaCO}_{3}\right)$ pada sampel air adalah sebesar $177,23 \mathrm{mg} / \mathrm{L}$, hal itu memenuhi aturan Per. Men. Kes yang mana tidak boleh melebihi ambang batas sebesar $500 \mathrm{mg} / \mathrm{L}$. Kadar nitrat pada sampel air adalah 7,441 mg/L, Konsumsi nitrat dalam jumlah yang berlebihan dan konsentrasi tinggi dapat menyebabkan keracunan karena dengan bantuan bakteri rumen, nitrat 
akan direduksi menjadi nitrit yang 10 kali lebih toksin dari nitrat. Pada hasil pemeriksaan nitrit memberikan hasil sebesar $<0,001 \mathrm{mg} / \mathrm{L}$ hasil tersebut memenuhi ambang batas yang disyaratkan, nitrit $\left(\mathrm{NO}_{2}{ }^{-}\right)$dihasilkan dari ubahan nitrat yang mengkontaminasi air minum oleh mikroorgnisme pada saluran pencernaan manusia. Keracunan nitrat atau nitrit dapat menyebabkan muka biru dan juga kematian. Pada pemgujian zat besi, menghasilkan kadar sebesar $0,018 \mathrm{mg} / \mathrm{L}$, hal ini sesuai dengan kadar yang disyaratkan. Besi $\left(\mathrm{Fe}^{3+}\right)$ dalam air menyebabkan warna air tersebut berubah menjadi kuning-cokelat setelah beberapa saat kontak dengan udara. Selain dapat mengganggu kesehatan juga dapat menimbulkan bau yang kurang enak. Kadar sulfat pada pengujian sampel air adalah sebesar 22,322 $\mathrm{mg} / \mathrm{L}$. Sulfat $\left(\mathrm{SO}_{4}\right)$ pada tingkat tinggi dapat memberikan zat rasa. Orang yang tidak terbiasa untuk minum air dengan kadar sulfat dapat mengalami diare dan dehidrasi. Hasil kadar cadmium saat pengujian adalah sebesar Ttd $(<0,001)$. Hal tersebut menunjukkan kadar air tidak tercemar oleh cadmium. Apabila cadmium melebihi standar, maka Cadmium akan terakumulasi dalam jaringan tubuh sehingga mengakibatkan penyakit ginjal, gangguan lambung, kerapuhan tulang, mengurangi hemoglobine darah dan pigmentasi (Tarigan, 2012).

Berdasarkan hasil yang dioleh pada keseluruhan parameter kimia yang diujikan menunjukkan bahwa air pada sumber mata air di Banjar Tatag, Desa Kukuh, Kecamatan Marga, Kabupaten Tabanan berada pada batas standar yang dibolehkan oleh Per. Men. Kes. RI. No. 492/MENKES/PER/IV/2010 tentang syaratan Kualitas Air Minum melalui parameter pemeriksaan kimia.

Hal itu menunjukkan bahwa, tingginya aktivitas pertanian pada daerah tersebut tidak mengganggu lingkungan airan di sumber mata air tersebut. Itu kemungkinan disebabkan oleh baiknya pengaturan aliran pembuangan sawahan, sehingga tidak mencemari sumber mata air di lingkungan tersebut.

b). Parameter Mikrobiologi

Berdasarkan hasil pemeriksaan pada parameter mikrobiologi yang dilakukan sebanyak tiga kali berturut-turut pada bulan Mei, Juli, dan September menunjukkan hasil adanya cemaran bakteri Fecal coli pada sampel mata air dengan jumlah pemeriksaan pada bulan Mei adalah sebesar 46 Fecal coli/100 mL; pada bulan Juli sebesar 13 Fecal coli/100 mL; serta pada bulan September sebesar 240 Fecal coli/100 mL.

Bakteri Fecal coli adalah bakteri yang berasal dari kotoran hewan dan manusia (Josephine,et.al., 2003). Faktor penyebab adanya pencemar bakteri pada sumber mata air di Banjar Tatag, Desa Kukuh, Kabupaten Tabanan kemungkinan disebabkan oleh dekatnya sumber mata air dengan lingkungan tempat tinggal penduduk, sehingga sisa-sisa hasil buangan limbah kotoran ternak hewan dan manusia kemungkinan mencemari sumber mata air tersebut. Dimana rata-rata setiap pemukiman penduduk di Banjar Dinas Tatag memiliki minimal satu kandang hewan ternak seperti babi, ayam, ataupun bebek.

Adanya kandungan bakteri pada air dapat menyebabkan efek terhadap kesehatan diantaranya radang lambung (gastroenteristis) dan diare yang hebat disertai dengan kram ut dan muntah-muntah, diare dapat menimbulkan dampak yang paling parah pada anak-anak atau orang tua yang sistem kekebalan tubuhnya lemah (Sulistyorini, 2016).

Adapun Per. Men. Kes. RI. No. 492/MENKES/PER/IV/2010 tentang syaratan Kualitas Air Minum memprasyaratkan untuk bakteri Fecal coli dalam 
jumlah $100 \mathrm{ml}$ sampel adalah 0. Maka dapat dikatakan bahwa air dari mata air Banjar Tatag, Desa Kukuh, Kabupaten Tabanan tidak layak untuk digunakan sebagai sumber air minum tanpa pengolahan berdasarkan hasil dari pengujian mikrobiologi yang telah dilakukan.

\section{SIMPULAN DAN SARAN}

\section{Simpulan}

Berdasarkan hasil penelitian yang telah dioleh, maka simpulan dalam penelitian ini adalah sebagai berikut:

1. Kualitas air pada sumber mata air di Desa Kukuh, Kecamatan Marga, Kabupaten Tabanan berdasarkan parameter kimia dan mikrobiologi menunjukkan hasil identifikasi kelayakan kualitas air minum yang telah dilakukan pada bulan (Mei, Juli, September) menunjukkan hasil: a). Parameter kimia menunjukkan bahwa seluruh parameter yang diujikan berada pada standar yang dibolehkan. b). Parameter mikrobiologi menunjukkan hasil adanya kandungan bakteri Fecal coli pada sampel mata air dengan jumlah rata-rata $100 \mathrm{Fecal} \mathrm{coli/100} \mathrm{mL}$.

2. Berdasarkan hasil identifikasi pada parameter kimia dan mikrobiologi menunjukkan bahwa hasil identifikasi parameter kimia sesuai dengan standar kualitas air minum yang ditetapkan oleh Per. Men. Kes. No. 492/MENKES/PER/IV/2010, sedangkan identifikasi pada parameter mikrobiologi menunjukkan hasil yang belum memenuhi baku mutu yang dibolehkan.

\section{Saran}

Berdasarkan hasil penelitian yang telah dioleh, maka saran dalam penelitian ini adalah sebagai berikut:

1. Kepada masyarakat disarankan agar masyarakat melakukan pengolahan air minum terlebih dahulu sebelum mengkonsumsi air dengan cara dimasak sampai mendidih, karena teridentifikasi adanya kandungan bakteri Fecal coli dalam sampel air mata air tersebut.

2. Kepada pihak terkait di Desa Kukuh, Kecamatan Marga, Kabupaten Tabanan agar melakukan manajemen pembuangan limbah kotoran ternak ataupun manusia untuk menghindari adanya kontaminasi bakteri Fecal coli pada sumber mata air.

\section{DAFTAR PUSTAKA}

Effendi, H. 2003. Telaah Kualitas Air. Edisi Kelima. Kanisius: Yogyakarta. Hal 14,17-18,146,148, 152-153.

Josephine A, Morello Paul A, Eckel Mizer GH. 2003. Laboratory manual and workbook in microbiology applications to patient care. Edisi ke-7. The McGraw-Hill Companies.

Sulistyorini, I. 2016. Analisis Kualitas Air Pada Sumber Mata Air di Kecamatan Karangan dan Kaliorang Kabupaten Kutai Timur. Edisi Maret 2016. Jurnal Hutan Tropis Volume 4 No. 1. Hal; 64-76. 
Omposunggu. 2009. Analisa Kandungan Nitrat Air Sumur Gali Masyarakat di Sekitar Tempa Pembuangan Akhir (TPA) Sampah di Desa Namo Bintang Kecamatan Pancur Ratu Kabupaten Serdang. Medan: Fakultas Kesehatan Masyarakat Universitas Sumatra Utara.

Peraturan Menteri Kesehatan Republik Indonesia Nomor 492/MENKES//IV/2010. Tentang syaratan Kualitas Air Minum. Jakarta: Departemen Kesehatan Republik Indonesia.

Rhidaton. 2013. Studi Kelayakan Mata Air Sebagai Sumber Air Minum di Desa Krueng Kulu Kecamatan Seunagan Timur Kabupaten Nagan Raya. Program Studi Ilmu Kesehatan Masyarakat: Aceh Barat. 